Annals of Warsaw University of Life Sciences - SGGW

Land Reclamation No 41 (2), 2009: 143-152

(Ann. Warsaw Univ. of Life Sciences - SGGW, Land Reclam. 41 (2), 2009)

\title{
Survey of plant species present on Constructed Wetlands in Opalenica Municipality
}

\author{
MARTA ŻMIREK ${ }^{1}$, STANISŁAW GAWROŃSKI ${ }^{2}$ \\ 1) ILF Consulting Engineers Polska Sp. z. o.o. \\ ${ }^{2)}$ Laboratory of Basic Natural Sciences in Horticulture, Warsaw University of Life Siences - SGGW
}

\begin{abstract}
Analysis and comparison of chosen constructed wetlands in Opalenica Municipality. The aim of this study was to analyse over fifty constructed wetlands established in two villages in Opalenica Municipality (Wielkopolska, Poland) differing in building time, prevailing hydrological and microclimatic conditions, appearance of macrophytes species and chosen plantation method. Two subsystems of constructed wetlands that are complementing one another, based on emergent macrophyte treatment system with vertical subsurface flow in plant filter and open water in denitrification ponds give the opportunity to the full-scale wastewater treatment performance. The main conclusions that can be drawn from this study regard the considerable role of the presence of macrophytes that significantly improve microbial activity, insulate against frost during winter, prevent from clogging and odour occurrence and improves value of the landscape. The conducted analyses proved that the establishment of this kind of semi-natural wastewater treatment system is becoming widely implemented into environmental protection schemes for rural communities.
\end{abstract}

Key words: constructed wetland, macrophyte, small community, wastewater treatment.

\section{INTRODUCTION}

The purpose of this study was to highlight the growing need for smallscale, passive, natural systems that can serve needs in water pollution control in small communities. From year 2003 to 2005 in Opalenica Municipality together in three villages 98 constructed wetlands were established and 51 of them were analysed in relation to occurring plant species, time of plantings and exploitation time, behaviour during winter time and other relevant aspects. Detailed analysis between water conditions and plant growth and percentage of occupied area gave the basis for evaluate the plant tendency to invasiveness and supplanting by each other.

Constructed wetlands (CWs) are a kind of wastewater treatment system that is based on imitation of commonly occurring processes found on natural wetlands. Wetlands improve the quality of water that flows through them by filtering out contaminants, actively degrading organic matter, and removing some chemicals that flow from upstream. The discovery of these chemical and physical properties led to the idea of intentionally using wetlands to treat wastewater. Biological treatment is mainly based on phytoremediation and microbiological processes that range the removal mechanisms of total suspended solids (TSS), biochemical oxygen demand (BOD), total nitrogen and phosphorus, heavy metals, organic contaminants and pathogens (Reed et al. 1995, Kadlec and Knight, 1996, Vymazal et al. 1998, Drizo et al. 1999, Stottmeister 
et al. 2003, Vega et al. 2003, Ciria et al. 2005, Ouellet-Plamondon et al. 2006). Although processes based on biological dependence between macrophytes and microorganisms, and their chemical reactions with the soil environment are already relatively well known, they are constantly under investigations. It turns out that many factors can influence, positively or negatively, on wastewater performance. Thus, present studies have marked out the main assignment: an improvement of constructed wetland system and its adaptation to alternating environment conditions.

There are many classifications of constructed wetlands. Various types are mainly differentiated by water flow mode and plant species characteristics. There are two types of commonly - used constructed wetlands: a) those that treat free water surface flow (FWS) with emerging; floating-leaved and submerged aquatic macrophytes; b) those that treat subsurface flow (SSF) with vertical flow and horizontal flow, both planted with emergent macrophytes (Birkedal et al. 1993).

\section{MATERIALS AND METHODS}

Study sites are located in Opalenica Municipality that consists of a town and adjacent villages, with both urban and rural areas. That is about $40 \mathrm{~km}$ west from Poznań, in Nowy Tomyśl County, Wielkopolskie Voivodeship, Poland. This research took into consideration two villages - Troszczyn with Sielinko Osada and Łęczyce, because the oldest CWs originated there and they have the most stabilized conditions.
Troszczyn and Sielinko Osada were taken into consideration as a one-study region, because of location nearness and consequent similar prevalent microclimatic conditions. In addition, the same time of building and constructed wetland technology was applied. Fiftyone CWs were assessed during summer 2005 (between July 27 and September 15).

The building design for Opalenica provided building constructed wetlands based on emergent macrophyte treatment system with vertical subsurface flow in plant filter and open water in ponds. The construction distinguished a septic tank (retention time amounts to four days), plant filter $\left(12 \mathrm{~m}^{2}\right)$ filled with sand, gravel and humix, a denitrification pond (its area is $5.7 \mathrm{~m}^{2}$ and useful volume about $1.3 \mathrm{~m}^{3}$ ) that removes nitrate nitrogen $\left(\mathrm{N}-\mathrm{NO}_{3}\right)$ from water, and an absorptive pond where water is led up to the ground. Absorptive ponds were built only in the constructed wetlands in Troszczyn and in Sielinko Osada, where high ground water level justified the need to create them.

The questionnaire was based on open, precise questions to get information and characteristics of each constructed wetland. The most important part of the investigation was the inventories of existing plants. Precise pictures that were taken on each site allowed to estimate covering surface of the filter and the pond by the species. On the sites owners were interviewed about: the number of members of the household, time of exploitation of the constructed wetland, source of seedlings and time of planting, whether sewage water is contaminated with some unusual chemical compounds 
because of some extra activity, wetland behaviour during winter, any noticed malfunctions like mosquitoes breeding, algae blooming, odour presence and other. After data completion the results were combined into record sheet and showed in tabulation.

\section{RESULTS}

Fifty-one constructed wetlands were assessed during summer 2005. In Troszczyn Village and in Sielinko Osada Village 32 sites were studied, and in Łęczyce 19 constructed wetlands were assessed. Fifteen constructed wetlands from Troszczyn were planted with emergent vegetation by owners themselves in contrast to the rest, that were planted with plants bought by the Municipality from The Institute of Applied Ecology in Skórzewo (the author of building design).

Together, on the constructed wetlands in the Opalenica Municipality fifteen species of macrophytes appeared 300 times including Lemna minor that occurred by accident.

On every site eight species should have been planted jointly (on plant filter and denitrification pond) according to the project, but sometimes there are only two of them and the rest of the plants are from out of the list. The average number of species found on sites is about 26 on plant filter and 32 on denitrification pond. There are eight new species introduced additionally. There is no observed correlation in combination of planned plants and the new ones. The project does not assume farming of common reed (Phragmites australis), which appeared on seven sites (two times on sites with plants from the Institute) and duckweed (Lemna minor) that appeared on ten sites, on each site with high number. The reason of presence of common reed can be found in botanical characteristics of the species, because it is considered as a highly invasive plant that propagates by air-borne seeds. The second possibility of occurrence of Phragmites australis on sites planted with the recommendation from the Institute is that the owners replanted some plants on they own.

There is a significant difference in number of appearing species in Łęczyce and in Troszczyn. On the studied sites in Łęczyce on plant filter totally eight plant species and in pond, 13 species can be found, and in Troszczyn 14 species on plant filter and 15 species in pond appeared respectively. Into these calculations was taken into consideration presence of Lemna minor in ponds that probably was introduced by waterfowl and appeared as a selfsown plant, however it improves biodiversity and wastewater treatment.

Percentage distribution indicates a significant difference in number of plants species growing on plant filter and in pond (Tab. 1). In Łęczyce Village it was about $14 \%$ more plants in pond and in Troszczyn $20 \%$ respectively. Taking into consideration the fact that almost all of the plants are helophytes that mainly grow in soils saturated with water or in the water itself, this dependence is comprehensible. The system of $\mathrm{CW}$ used in the project assumed vertical subsurface flow on plant filter and open water in ponds. The subsurface flow system is characterized by water 
TABLE 1. Number of plants within given plant species present on plant filter and in pond at Łęczyce and Troszczyn

\begin{tabular}{|c|c|c|c|c|c|c|c|c|c|c|}
\hline \multirow{2}{*}{$\begin{array}{l}\text { Plant } \\
\text { species }\end{array}$} & \multicolumn{4}{|c|}{ Łęczyce } & \multicolumn{4}{|c|}{ Troszczyn } & \multicolumn{2}{|c|}{ Summary } \\
\hline & $\begin{array}{l}\text { Plant } \\
\text { filter }\end{array}$ & $\begin{array}{l}\% \text { of } \\
\text { total }\end{array}$ & Pond & $\begin{array}{l}\% \text { of } \\
\text { total }\end{array}$ & $\begin{array}{l}\text { Plant } \\
\text { filter }\end{array}$ & $\begin{array}{l}\% \text { of } \\
\text { total }\end{array}$ & Pond & $\begin{array}{l}\% \text { of } \\
\text { total }\end{array}$ & Total & $\begin{array}{l}\% \text { of } \\
\text { both } \\
\text { location }\end{array}$ \\
\hline Carex acutiformis & 15 & 5.0 & 6 & 2.0 & 25 & 8.3 & 12 & 4.0 & 58 & 19.3 \\
\hline Scirpus lacustris & 3 & 1.0 & 11 & 3.7 & 5 & 1.7 & 12 & 4.0 & 31 & 10.3 \\
\hline Juncus effusus & 15 & 5.0 & 5 & 1.7 & 5 & 1.7 & 4 & 1.3 & 29 & 9.7 \\
\hline Glyceria maxima & 11 & 3.7 & 4 & 1.3 & 7 & 2.3 & 5 & 1.7 & 27 & 9.0 \\
\hline Phalaris arundinacea & 11 & 3.7 & 0 & 0.0 & 12 & 4.0 & 1 & 0.3 & 24 & 8.0 \\
\hline Typha angustifolia & 1 & 0.3 & 7 & 2.3 & 5 & 1.7 & 10 & 3.3 & 23 & 7.7 \\
\hline Iris pseudoacorus & 1 & 0.3 & 4 & 1.3 & 1 & 0.3 & 15 & 5.0 & 21 & 7.0 \\
\hline Sparganium erectum & 1 & 0.3 & 10 & 3.3 & 2 & 0.7 & 6 & 2.0 & 19 & 6.3 \\
\hline $\begin{array}{l}\text { Alisma plantago-aqua- } \\
\text { tica }\end{array}$ & 0 & 0.0 & 9 & 3.0 & 1 & 0.3 & 7 & 2.3 & 17 & 5.7 \\
\hline Typha latifolia & 0 & 0.0 & 1 & 0.3 & 6 & 2.0 & 7 & 2.3 & 14 & 4.7 \\
\hline Phragmites australis & 0 & 0.0 & 0 & 0.0 & 5 & 1.7 & 6 & 2.0 & 11 & 3.7 \\
\hline Acorus calamus & 0 & 0.0 & 3 & 1.0 & 1 & 0.3 & 3 & 1.0 & 7 & 2.3 \\
\hline Alisma lanceolatum & 0 & 0,0 & 1 & 0.3 & 1 & 0.3 & 3 & 1.0 & 5 & 1.7 \\
\hline Lythrum salicaria & 0 & 0.0 & 1 & 0.3 & 2 & 0.7 & 1 & 0.3 & 4 & 1.3 \\
\hline Lemna minor & 0 & 0.0 & 5 & 1.7 & 0 & 0.0 & 5 & 1.7 & 10 & 3.3 \\
\hline Sum & 58 & 19.3 & 67 & 22.3 & 78 & 26.0 & 97 & 32.3 & 300 & 100.0 \\
\hline
\end{tabular}

percolation through the medium (gravel, sand, other) under the filter surface. In this case, water saturation in the plant filter can be not sufficient for optimal plant growth and in comparison, better habitat conditions prevail in ponds.

In addition, the combination of the planted plants in the majority of cases is accidental, even though only 15 from 51 of active constructed wetlands were planted by owners themselves. Plants planted by the Institute employees differ significantly from these recommended in the project's assumptions, also during 2003-2005 the combination of plants planted has been changed. Additionally there is no data about how many stands were planted, how many of them did not rooted or fell out during winter. Thus, the analyses should ranged data about plants that were found on sites and their strength, general conditions and environmental entourage. The constructed wetlands in the Municipality should not be analyzed with regard to species appearance all together because of the different building time, prevailing hydrological and microclimatic conditions and chosen plantation method. In addition, number of household members and consequential water consumption - all of these factors should have an influence on percentage distribution of each species. However, the correlation between amount of occupied area by species on plant filters and ponds can be 
observed. Here are presented the data of how many times each species appeared on area that is lower than $15 \%$, area from 15 to $50 \%$, and on area over $50 \%$ of surface area of plant filter and pond (Tab. 2).

This data shows visibly that some of the plant species prefer for example flooded habitats to the wet ones on the plant filter, where there is no water on the surface. Furthermore, there are cases of constructed wetlands, where the entire area is occupied by vegetation, both in plant filter and in pond, which means that there is probability of space and nutrient competition between species.

TABLE 2. Percentage of the area occupied by plants on plant filter and in pond

\begin{tabular}{|c|c|c|c|c|c|}
\hline \multirow{2}{*}{ Plant species } & \multirow{2}{*}{ Location $\%$} & \multicolumn{4}{|c|}{$\%$ of total } \\
\hline & & $<15$ & $15-50$ & $>50 \%$ & Sum \\
\hline \multirow{2}{*}{ Carex acutiformis } & Filter & 11 & 20 & 9 & 40 \\
\hline & Pond & 13 & 2 & 3 & 18 \\
\hline \multirow{2}{*}{ Scirpus lacustris } & Filter & 6 & 2 & - & 8 \\
\hline & Pond & 12 & 9 & 2 & 23 \\
\hline \multirow{2}{*}{ Juncus effusus } & Filter & 13 & 3 & 4 & 20 \\
\hline & Pond & 5 & 3 & 1 & 9 \\
\hline \multirow{2}{*}{ Glyceria maxima } & Filter & 4 & 6 & 8 & 18 \\
\hline & Pond & 5 & 2 & 2 & 9 \\
\hline \multirow{2}{*}{ Phalaris arundinacea } & Filter & 12 & 9 & 2 & 23 \\
\hline & Pond & 1 & - & - & 1 \\
\hline \multirow{2}{*}{ Typha angustifolia } & Filter & 3 & 3 & - & 6 \\
\hline & Pond & 7 & 7 & 3 & 17 \\
\hline \multirow{2}{*}{ Iris pseudoacorus } & Filter & 1 & 1 & - & 2 \\
\hline & Pond & 12 & 4 & 3 & 19 \\
\hline \multirow{2}{*}{ Sparganium erectum } & Filter & 2 & 1 & - & 3 \\
\hline & Pond & 5 & 7 & 4 & 16 \\
\hline \multirow{2}{*}{ Alisma plantago-aquatica } & Filter & 1 & - & - & 1 \\
\hline & Pond & 9 & 6 & 1 & 16 \\
\hline \multirow{2}{*}{ Typha latifolia } & Filter & 4 & 1 & 1 & 6 \\
\hline & \begin{tabular}{|l|} 
Pond \\
\end{tabular} & 3 & 4 & 1 & 8 \\
\hline \multirow{2}{*}{ Phragmites australis } & Filter & 2 & 2 & 1 & 5 \\
\hline & Pond & 1 & 4 & 1 & 6 \\
\hline \multirow{2}{*}{ Acorus calamus } & Filter & 1 & - & - & 1 \\
\hline & \begin{tabular}{|l|} 
Pond \\
\end{tabular} & 4 & 2 & - & 6 \\
\hline \multirow{2}{*}{ Alisma lanceolatum } & Filter & 1 & - & - & 1 \\
\hline & Pond & 4 & - & - & 4 \\
\hline \multirow{2}{*}{ Lythrum salicaria } & Filter & 2 & - & - & 2 \\
\hline & Pond & 1 & 1 & - & 2 \\
\hline \multirow{2}{*}{ Lemna minor } & Filter & - & - & - & - \\
\hline & Pond & - & 2 & 8 & 10 \\
\hline
\end{tabular}




\section{DISCUSSION AND SUMMARY}

In comparison of constructed wetlands in Lęczyce, the bigger biodiversity can be found on sites in Troszczyn. The first reason is the higher number of CWs of about $36 \%$, thus probability of a new species appearance is bigger. However, Troszczyn Village is located in the area, where the unconfined groundwater table is found on depth about 1-2 $\mathrm{m}$ below ground level. In the north part of the Municipality, where Łęczyce Village is situated the groundwater table is decreasing to $5 \mathrm{~m}$ below the ground level and in some places even to $10 \mathrm{~m}$ below the ground level. In addition, the landscapes of both localities differ significantly, the area of Troszczyn is full of greenery, field stands, and the microclimate is more humid in contrast to Łęczyce, where the vegetation is poorer and plain arable landscapes prevail giving a feeling of drought. The third reason of higher number of species growing in Troszczyn is that fifteen (almost half) constructed wetlands were planted by owners themselves, thus plants were taken from local sources, usually from nearby located ditches, riverbanks or lake banks. This can ensure that planted local varieties of species are well chosen to prevailing microclimatic conditions. In addition, the fact that constructed wetlands in Troszczyn are older and time predominance in plantings, in comparison to CWs in Łęczyce, amounts in some cases even to three vegetative seasons gives the basis to higher biological diversity due to more stabilized and mature ecosystem conditions. Amongst the fifteen plant species, the most common species founded on sites is Carex acutiformis (Tab. 1). In both villages, it appears the most frequently on plant filters and it is frequent in ponds. This plant can be rated among accommodative species, and its fast spreading can be explained by existing favourable conditions on CW's plant filters. However, in ponds this species is not so numerous, the reason of this situation can be found in the botanical characteristics of $C$. acutiformis. Its habitat includes shallow waters, and in some cases, the water depth in ponds reaches even $1 \mathrm{~m}$, thus better-adapted plants like Scirpus lacustris, Sparganium erectum, Alisma plantago-aquatica, Typha angustifolia and Iris pseudoacorus.

During winter in the Opalenica Municipality in some cases, only partial water freezing was observed in ponds. In 17 cases, thin layer of ice had formed, but most owners had no problem with constructed wetlands' maintenance during winter. When outdoor temperature is decreasing, wetland plants die and microbial activity drops off. On the other hand, constructed wetlands were reported to perform many treatment functions efficiently in winter and can regularly operate under ice layers, when the average temperature is lower than $-4^{\circ} \mathrm{C}$. Thus on the basis of scientific researches the treatment functions are better fulfilled when ice layer occurs, because the air space that is created between water and ice layer insulates the water underneath. In addition, the snow cover lying on the top of the ice additionally improves insulation. Furthermore, the important maintenance feature is leaving harvesting plants in autumn on plant filter 
surface as a natural insulation, according to assumptions contained in project.

The average number of household members, where constructed wetlands are active is five, although the project assumed, that a constructed wetland, which is to be used by an average family consisting of six members. Only seven households fulfilled this assumption. Twelve households have number of occupants that is higher than six, and the 33 households have the lower number than six, however there is no correlation between number of members (and consequential wastewater volume) and species appearance or number of plants species. Constructed wetlands next to household with 1 occupant as well as with 14 ones have similar amounts of plant species.

During conducting the research in four cases green water was observed, probably because of algae blooming. The reason of that can be found in high concentrations of biogenic compounds in water, specially the nitrogen. Nutrient enriched wastewaters are promoting flourishing growth of algae in the surface flow system, which tends to reduce treatment performance. In case of toxic and blue - green algae bloom, it can lead to secondary pollution of water in ponds, but further investigation would be required to test what kinds of algae we have to do with. On two constructed wetlands were installed fountains in ponds. During water abstraction, heavy particulates from the already settled total suspended solids were also sucked in and dragged into the pipe system. In both cases on the surface of water in ponds were founded a thin layers of suspended solids. On one $\mathrm{CW}$ was noticed appearance of water odour that was probably caused by putrefaction processes and created anaerobic condition due to lack of vegetation in pond. Thus, replantations in the pond are required.

The efficiency of wastewater treatment on constructed wetland is mainly dependent on the chosen flow system, planted plants, retention time. Analyzed prior researches ranged in the first place tests of effectiveness individual cells planted by one different plant each. In the Opalenica Municipality the combinations of several (up to even ten) species occur. Until the beginning of 2006, there were no physical or chemical laboratory analyses, so the authentic efficiency and project assumptions' fulfilment is not known and further investigation would be required to test.

Most of the species were appropriately chosen to perform treatment functions efficiently on constructed wetlands. However, on basis of some botanical characteristics and observations that were made during research, some conclusions were drawn below. Lesser pond sedge (Carex acutiformis) the most frequently appears on plant filter with occupation from 15 to $50 \%-20$ times, but also incidence in other two groups is significant. In pond, the situation of plant looks different - in 13 cases, it occupies lower areas and only in five ponds takes up area bigger than $15 \%$. This survey shows that the best habitat for C. acutiformis is characterized with wet eutrophic sites, but not flooded, and there it can create big groups of a dozen stands. Bulrush (Scirpus lacustris) when occurs on plant filters it is on small areas in little amounts. There is no situation, where it would occupy more than $50 \%$ 
of area. Nevertheless, in ponds, water habitat conditions are better fulfilled and appearance in bigger groups is more frequent, on the area over the $15 \%$ bulrush is founded eleven times. Juncus effusus - common rush - prefers wet habitats as well as flooded localities like ponds. However, on plant filters, where subsurface flow exists, it creates bigger complexes of a single stands, which is compatible with its botanical characteristics. On plant filters, reed sweet-grass (Glyceria maxima) creates big groups of dozen plant stands, which suggests the invasive character of the plant. Also in ponds, this species appears frequently, but in bigger number in the form of single plantations with the occupation up to $15 \%$ of the pond surface. The results showed a significant manner that the reed canarygrass (Phalaris arundinacea) prefers moisture areas to habitats with open water. On plant filters occurs in big amounts, with prevalence to occupying small areas up to $50 \%$. In pond, it is planted one time and it grows near the edge of the reservoir. Narrow-leaved cattail (Typha angustifolia) is more often found in water environment, where occupies over a half of the pond as well as small areas. It also takes part in overgrowing, which can be noticed in older constructed wetlands, where presence of competitive species is insignificant. On plant filter occurs in small amounts as a single stands. Based on the analyzed occupying percentage of the area of paleyellow iris (Iris pseudoacorus) this plant prefers water habitat conditions to moisture habitats. Only two times was founded on plant filter. However, it is not in the habit of creating big concentrations, rather occurs individually. Sparganium erectum - branched bur-reed - rarely creates big groups, rather appears single or in small clusters according to botanical description. More frequently grows in standing water than on filter. On constructed wetlands' ponds in the Opalenica Municipality is founded 16 times whereof four times on the area of over $50 \%$. Common water plantain (Alisma plantago-aquatica) is a typical helophyte thus the appearance frequency in the pond is significant and amount to 16. Nevertheless, it is not characterised by predisposition to creates greater fields, so dominant form it occurs in is the single stand. Although broad-leaved cattail is commonly regarded as a mainly water macrophyte, it is also found on plant filters. Typha latifolia occurs there usually individually. However, on sites, where there is no other plant except for common reed, it acts as a highly invasive species that plays significant role in overgrowing. In ponds, it grows on small areas taking up maximum 50\%. Phragmites australis occurs both on lands and standing or floating waters, which is reflected in the results of this study. It is regarded a as highly invasive species that creates homogeneous stands in water, but on constructed wetlands shows moderate growth, with a small tendency to overgrowing the reservoirs. Although its plantation is not recommended by project, presence of this species improves wastewater performance, which is confirmed by lots of worldwide researches and in practice. Sweet flag (Acorus calamus) occurs not frequently, however most commonly on water habitats. There is no observed tendency to overgrowing 
and the occupied area is usually lesser than $50 \%$ of the pond surface. Founded plants were in form of the individual stands. Alisma lanceolatum - lanceleaf water plantain - occurred on five sites, whereof only once on plant filter, which indicates mainly water character of the plant. The species do not create bigger groups. In all of the cases, it was founded as a single specimen. Purple loosestrife occurs widely in wet habitats as well as in shallow waters. On the constructed wetlands does not occur frequently, but mainly on sites planted or replanted by owners themselves. Lythrum salicaria is found as a very common and invasive species, due to its very good adaptabilities. However, on checked sites it occupies small areas and has no tendency to overgrowing. Duckweed (Lemna minor) that appeared accidentally positively affects the wastewater treatment and improves biodiversity. Its habitat is standing waters, thus it occurs only in ponds. It is characterized by high tolerance for nitrogen compounds, water pollution by communal wastewaters, eutrophication, and shade, that is why is founded as an invasive species. On studied sites occupies area of over $50 \%$, in majority of cases it is the entire pond surface.

\section{CONCLUSIONS}

1. Presence of macrophytes: insulates against frost during winter, prevents from odours occurrence, makes wastewater treatment systems aesthetically pleasing and improves value of the landscape.
2. Full water saturation conditions that exist in ponds are more favourable for helophytes growth than subsurface wastewater flow system dominating in plant filter.

3. Higher level of system stability is ensured by plant complementing in phytoremediation.

4. Building of constructed wetlands is a simple solution of wastewater treatment for small and rural communities that can successfully take place of previous used systems like septic tanks or drainage sewage treatment plants.

\section{REFERENCES}

BIRKEDAL K., BRIX H., JOHANSEN N.H. 1993: Wastewater Treatment in Constructed Wetland-Designers Manual. The Management Institute, Ebeltoft, Denmark.

CIRIA M.P., SOLANO M.L., SORIANO P. 2005: Role of macrophyte Typha latifolia in a constructed wetland for wastewater treatment and assessment of its potential as a biomass fuel. Biosystems Engineering 92 (4): 535-54

DRIZO A., FROST C.A., GRACE J., SMITH K.A. 1999: Physico-chemical screening of phosphate-removing substrates for use in constructed wetland systems. Water Research 33 (17): 3595-3602.

KADLEC R.H., KNIGHT R.L. 1996: Treatment Wetlands. Lewis Publishers, Boca Raton, Florida, USA.

OUELLET-PLAMONDON C., CHAZARENC F., COMEAU Y., BRISSON J. 2006: Artificial aeration to increase pollutant removal efficiency of constructed wetlands in cold climate. Ecological Engineering 27: 258-264

REED S.C., CRITES R.W., MIDDLEBROOKS J.E. 1995: Natural Systems for Waste Management and Treatment. 
Second Edition. McGraw-Hill Inc., New York.

STOTTMEISTER U., WIESSNER A., KUSCHK P., KAPPELMEYER U., KASTNER M., BEDERSKI O., MÜLLER R.A., MOORMANN H. 2003: Effects of plants and microorganisms in constructed wetlands for wastewater treatment. Biotechnology Advances 22: 93-117.

VEGA E., LESIKAR B., PILLAI S.D. 2003: Transport and survival of bacterial and viral tracers through submerged-flow constructed wetland and sand-filter system. Bioresource Technology 89 (1): 49-56.

VYMAZAL J., BRIX H., COOOPER P.F., HABERL R., LABER J. 1998: Constructed wetlands for wastewater treatment in Europe, Backhuys Publishers, Leiden, The Netherlands.

Streszczenie: Analiza i porównanie wybranych przydomowych oczyszczalni hydrofitowych na terenie Gminy Opalenica. Celem tej pracy była analiza ponad pięćdziesięciu oczyszczalni hydrofitowych, założonych na terenie Gminy Opalenica w województwie wielkopolskim. Ocenie podlegał czas budowy, obecność poszczególnych gatunków roślin, ich źródło i czas nasadzenia, zachowanie się oczyszczalni w okresie zimowym oraz informacja o występowaniu ewentualnych problemów. Badania objęły dwie wsie różniące się od siebie położeniem oraz wynikającymi z tego warunkami hydrogeologicznymi. Dzięki ankietom opartym na otwartych pytaniach uzyskano potrzebne informacje i charakterystykę każdej z badanej oczyszczalni. Stworzony został również spis roślin występujących w analizowanych stanowiskach oraz dokładna dokumentacja fotograficzna. Podstawowym wnioskiem nasuwającym się po przeprowadzonej analizie jest znacząca rola roślin wodnych, których obecność wpływa na przeciwdziałanie zamarzaniu w okresie zimowym, na brak odorów oraz na podniesienie wartości krajobrazu. Szczegółowa analiza zajmowanej powierzchni przez poszczególne gatunki na filtrze roślinnym, gdzie panują warunki wilgotne oraz w stawie, umożliwiła oszacować ewentualną tendencje gatunków do ekspansji i wypierania innych roślin, jak również określić optymalne warunki wodne dla rozwoju makrofitów. Dodatkowym atutem wpływającym na efektywność oczyszczania wody jest sama konstrukcja oczyszczalni, złożona z dwóch podsystemów uzupełniających się nawzajem. Filtr obsadzony roślinnością wodną z pionowym, podpowierzchniowym systemem przepływu ścieków oraz staw denitryfikacyjny dają możliwość oczyszczenia ścieków na pełną skalę.

\section{MS. received November 2009}

\section{Authors' addresses:}

Marta Żmirek, 02-761 Warszawa, ul. Korsykańska 1 m. 99

Stanisław W. Gawroński

Laboratory of Basic Natural Sciences in

Horticulture, Warsaw University of Life Siences

- SGGW

02-677 Warszawa, ul. Nowoursynowska 159

Poland 